\title{
Decrease in leptin production by the adipose tissue in obesity associated with severe metabolic syndrome
}

\author{
Diminuição da produção de leptina pelo tecido adiposo na \\ obesidade associada à síndrome metabólica severa
}

Gilberto Jorge da Paz-Filho', Alexei Volaco', Henrique Lacerda Suplicy', Rosana Bento Radominski', Cesar Luiz Boguszewski'

1 Serviço de Endocrinologia e Metabologia, Hospital de Clínicas, Universidade Federal do Paraná (SEMPR-UFPR), Curitiba, PR, Brasil
Correspondence to:

Cesar Luiz Boguszewsk Departamento de Medicina Interna, Serviço de Endocrinologia e Metabologia, Hospital de Clínicas, UFPR

Av. Agostinho Leão Junior, 285 80030-110 - Curitiba, PR, Brasil cesarluiz@hc.ufpr.br

Received on July/8/2009 Accepted on Aug/3/2009

\begin{abstract}
Objective: To evaluate the associations between leptinemia and the components of metabolic syndrome (MetS). Methods: Fifty-one obese adults ( 9 men; $36.7 \pm 10.0$ years; body mass index (BMI) $46.2 \pm 10.0 \mathrm{~kg} / \mathrm{m}^{2}$ ) were submitted to clinical examination, determinations of body fat mass ( $B F$, bioimpedance) and resting energy expenditure ( $R E E$, indirect calorimetry), and to hormonal and biochemical analysis. Patients were categorized into three groups, according to the number of criteria for MetS: Group I: none or 1; Group II: 2; and Group III: 3 or 4 criteria. Results: Absolute leptinemia (LepA; $37.5 \pm 16.9 \mathrm{ng} / \mathrm{mL}$ ) was directly correlated with BMI $(r=0.48 ; p=0.0004)$, waist circumference $(r=0.31 ; p=0.028)$ and $B F(r=0.52 ; p=0.0001)$. Leptinemia adjusted for BF (LepBF) was inversely correlated with weight $(r=-0.41 ; p=0.027)$, REE $(r=-0.34 ; p=0.01)$ and number of MetS criteria $(r=-0.32 ; p=0.02)$. There was no difference in LepA among the groups. LepBF in Group III $(0.58 \pm 0.27 \mathrm{ng} / \mathrm{mL} / \mathrm{kg})$ was significantly lower compared to Group I ( $0.81 \pm 0.22 \mathrm{ng} / \mathrm{mL} / \mathrm{kg} ; \mathrm{p}=0.03)$ and Group II $(0.79 \pm 0.30 \mathrm{ng} / \mathrm{mL} / \mathrm{kg} ; \mathrm{p}=0.02)$. Conclusions: Leptin production by the adipose tissue is decreased in obese subjects fulfilling three or more criteria of MetS, suggesting a state of relative leptin deficiency in obesity associated with advanced stages of MetS. Arq Bras Endocrinol Metab. 2009;53(9):1088-95
\end{abstract}

Keywords

Leptin; adipokines; obesity; metabolic syndrome; leptinemia

\section{RESUMO}

Objetivo: Avaliar as associações entre leptinemia e os componentes da síndrome metabólica (MetS). Métodos: Cinquenta e um adultos obesos (9 homens, 36,7 $\pm 10,0$ anos, índice de massa corpórea, IMC, 46,2 $\pm 10,0 \mathrm{~kg} / \mathrm{m}^{2}$ ) foram submetidos à avaliação clínica, a determinações da massa adiposa ( $B F$, bioimpedância) e do gasto energético basal (REE, calorimetria indireta) e a análises hormonais e bioquímicas. Os pacientes foram divididos em três grupos, de acordo com o numero de critérios para MetS: Grupo I, nenhum ou 1; Grupo II: 2; e Grupo III: 3 ou 4 critérios. Resultados: A leptinemia absoluta (LepA; $37,5 \pm 16,9 \mathrm{ng} / \mathrm{mL}$ ) se correlacionou diretamente a IMC $(r=0,48 ; p=0,0004)$, circunferência abdominal $(r=0,31 ; p=0,028)$ e $B F(r=0,52 ; p=0,0001)$. A leptinemia ajustada por BF (LepBF) se correlacionou inversamente ao peso $(r=-0,41 ; p=0,027)$, ao REE $(r=-0,34 ; p=0,01)$ e ao número de critérios para MetS $(r=-0,32 ; p=0,02)$. Não houve diferença de LepA entre os grupos. LepBF no Grupo III $(0,58 \pm 0,27 \mathrm{ng} / \mathrm{mL} / \mathrm{kg})$ foi significativamente menor que no Grupo I $(0,81 \pm 0,22 \mathrm{ng} / \mathrm{mL} / \mathrm{kg} ; \mathrm{p}=0,03)$ e II $(0,79 \pm 0,30 \mathrm{ng} / \mathrm{mL} / \mathrm{kg} ; \mathrm{p}=0,02)$. Conclusões: A produção de leptina pelo tecido adiposo está diminuída em pacientes obesos que preenchem três ou mais critérios para MetS, sugerindo um estado de deficiência relativa de leptina na obesidade associada a estágios avançados de MetS. Arq Bras Endocrinol Metab. 2009;53(9):1088-95 Descritores

Leptina; adipocinas; obesidade; síndrome metabólica; leptinemia 


\section{INTRODUCTION}

$\mathrm{O}$ besity is a chronic disease that has reached epidemic proportions worldwide. According to the World Health Organization (WHO), over a billion adults are overweight, and at least $\mathbf{3 0 0}$ million are obese - defined as body mass index (BMI) over $30 \mathrm{~kg} / \mathrm{m}^{2}(1)$. Among Brazilians above age 20,40.6\% are overweight and $11 \%$ are obese $(2)$.

The increasing prevalence of obesity leads to the development of common metabolic disturbances, such as atherogenic dyslipidemia, elevated arterial blood pressure, insulin resistance or hyperglycemia, inflammation and prothrombotic states. The association of these disturbances with visceral obesity is defined as metabolic syndrome (MetS) (3).

Leptin, the product of the $O B$ gene, plays an important role in this homeostatic system. Among other actions, leptin regulates food intake stimulating hypothalamic anorexigenic pathways and inhibiting orexigenic ones $(4,5)$. In addition, leptin has been associated with MetS in completely leptin-deficient animals and humans (6-11), as well as in partially-deficient models (12).

In the periphery, leptin attenuates the lipogenic and oxidative actions of insulin, increases $\beta$-oxidation of nonesterified fatty acid (NEFA) and decreases its esterification into triacylglycerol (13). Taken together, peripheral actions of leptin decrease lipogenesis and protect against tissue lipotoxicity $(14,15)$. Thus, decreased leptin production by adipose tissue might potentially contribute to the development of MetS.

Leptin has been implicated in inflammation, thrombogenesis and fibrinolysis (16-18), but it is yet unclear whether leptin is merely a biomarker of MetS and cardiovascular disease $(16,19)$, or whether it is directly involved in the pathogenesis of those conditions (16,20-24).

In this study, we aimed to evaluate whether leptinemia is associated with the components of MetS and its severity. To achieve that objective, we evaluated both absolute leptin levels (LepA) and leptin levels adjusted for body fat (LepBF) in obese subjects who fulfilled 0-1, 2 or 3-4 of the International Diabetes Federation (IDF) criteria for MetS (25), and correlated the values with their anthropometric, metabolic and hormonal parameters.

\section{PATIENTS AND METHODS}

\section{Patients}

This was a cross-sectional study of a consecutive cohort of adult obese patients followed-up in the Obesity
Outpatient Clinic of the Hospital de Clínicas of Universidade Federal do Paraná (UFPR), Curitiba, Brazil. From June to December 2006, a total of 225 medical records from patients with BMI $>30 \mathrm{~kg} / \mathrm{m}^{2}$ was reviewed for the selection of patients eligible for the study. Only adult obese patients whose weight had been stable in the previous three months and who agreed to participate were included. We excluded pregnant women, patients with severe comorbidities or chronic diseases, with evidence of secondary obesity due to genetic, endocrine, metabolic or neurologic disorders, and patients who received during the past 12 months corticosteroids, antidiabetic therapy, antiobesity drugs or any other pharmacologic agent known to influence body weight or serum leptin levels.

\section{Methods}

Clinical examination and anthropometric measurements were performed by the same investigator in the morning, while subjects were fasting for 12 hours. Starting from the day before measurements, patients were advised not to take any drugs, not to engage into physical activity and to drink at least $2 \mathrm{~L}$ of water over 24 hours.

Arterial blood pressure was measured twice, while patients were sitting, with a 10 -minute interval. The average of the two measurements was used for the analysis. Patients were weighed while wearing light street clothes on a digital scale with $0.01-\mathrm{kg}$ increments (PL-180 LED, Filizola Balanças Industriais, São Paulo, SP, Brazil). Heights were measured using a stadiometer attached to the same scale, with $0.5-\mathrm{cm}$ increments. Waist circumference (WC) was measured with a flexible measuring tape with $0.1-\mathrm{cm}$ increments, by placing the tape on the widest abdominal perimeter between the last rib and the iliac crest, parallel to the floor, while standing.

Body fat mass (BF, in $\mathrm{kg}$ ) was measured by bioelectric impedanciometry (BIA 310 bioimpedance analyzer, Biodynamics Corporation, Seattle, WA, USA). The Lohman equation for obese individuals was used to determine BF. Resting energy expenditure (REE) was assessed by indirect calorimetry (Deltatrac II, SensorMedics, Anaheim, CA, USA). Briefly, REE was estimated from oxygen consumption $\left(\mathrm{VO}_{2}\right)$ and carbon dioxide production $\left(\mathrm{VCO}_{2}\right)$ measured during 30 minutes, and extrapolated to 24 hours.

A 12-hour fasting morning blood sample was collected once from each subject for measurements of glucose, insulin, total cholesterol (TC), triglyceride (TGC), and high-density lipoprotein (HDL) cholesterol by routine methods at our laboratory. Low-density lipo- 
protein (LDL) cholesterol values were obtained from Friedewald equation: LDL $=\mathrm{TC}-(\mathrm{HDL}+\mathrm{TGC} / 5)$. Aliquots of blood sample were used for determination of TSH (chemiluminescence, DPC, Los Angeles, CA, normal range $0.4-4.0 \mu \mathrm{UI} / \mathrm{mL}$, limit of detection 0.03 $\mu \mathrm{UI} / \mathrm{mL}, \mathrm{CV} 3.8-12.5 \%$ ), free T4 (chemiluminescence, DPC, Los Angeles, CA, normal range 0.8-1.8 ng/ $\mathrm{dL}, \mathrm{CV}$ 4.4-9.0\%), insulin (chemiluminescence, DPC, Los Angeles, CA, normal range 6-27 $\mu \mathrm{UI} / \mathrm{mL}$, limit of detection $2 \mu \mathrm{UI} / \mathrm{mL}, \mathrm{CV} 3.9-4.9 \%$ ), and leptin (radioimmunoassay, HL-81HK, Linco Research Inc., St. Charles, MO, USA, limit of detection $0.5 \mathrm{ng} / \mathrm{mL}, \mathrm{CV}$ 3.4-8.3\%). Samples for leptin were assayed in duplicate, and the mean CV was $5.55 \pm 4.68 \%$. Leptin levels were expressed as absolute leptinemia $(\mathrm{ng} / \mathrm{mL}$; LepA) and as leptinemia adjusted for BF $(\mathrm{ng} / \mathrm{mL} / \mathrm{kg}$; LepBF). The homeostatic model assessment of insulin resistance index (HOMA-IR) was calculated according to the equation: fasting glucose $(\mathrm{mmol} / \mathrm{L}) \mathrm{x}$ fasting insulin $(\mu \mathrm{U} /$ $\mathrm{mL}) / 22.5$.

Based on the clinical, anthropometric and laboratory data, we categorized the patients into three groups, using the IDF criteria for diagnosis of MetS (25). Those criteria require the presence of central obesity (defined as increased WC, adjusted for gender and different ethnic groups) associated with two or more of the following criteria:

1. elevated triglycerides ( $\geq 150 \mathrm{mg} / \mathrm{dL}$ ) or specific treatment for hypertriglyceridemia;

2. reduced HDL cholesterol $(<50 \mathrm{mg} / \mathrm{dL}$ in females and $<40 \mathrm{mg} / \mathrm{dL}$ in males) or specific treatment for this lipid abnormality;

3. elevated blood pressure (systolic $\geq 130 \mathrm{mmHg}$ or diastolic $\geq 85 \mathrm{mmHg}$ ) or treatment for previously diagnosed hypertension;

4. elevated fasting plasma glucose $(\geq 100 \mathrm{mg} / \mathrm{dL})$ or previously diagnosed type 2 diabetes mellitus (T2DM) (25).

Patients were categorized into one of the three groups: Group I (patients with central obesity who fulfill 0 or 1 criterion for MetS), Group II (patients with central obesity who fulfill 2 criteria for MetS) and Group III (patients with central obesity who fulfill 3 or 4 criteria for MetS). Since all patients had BMI > 30 $\mathrm{kg} / \mathrm{m}^{2}$ all of them were assumed to have central obesity according to the IDF recommendations.

The study was approved by the Ethics Committee for Research in Human Beings of Hospital de Clínicas of UFPR, and a written Informed Consent was given by all subjects.
Statistical analysis was performed using the Statgraphics Plus for Windows 3.0 (Manugistics, Inc., Rockville, MD, USA) and STATISTICA 7.0 (Statsoft, Inc, Tulsa, OK, USA). Data were reported as means \pm standard deviation (SD), and $\mathrm{p}<0.05$ was considered to be significant. Measures of central tendency and variability were calculated for continuous variables. Synthetic tables of frequency were elaborated for qualitative variables. Distribution was determined by the KolmogorovSmirnov and Lilliefors tests. Parametric tests (ANOVA) were used when distribution was normal, whereas the Kruskal-Wallis test was used when distribution was asymmetric. Pearson's or Spearman's correlation coefficients were used to determine the correlation between variables, according to the type of distribution.

\section{RESULTS}

The study group consisted of 51 obese participants. Six patients had obesity class I $\left(B M I=30-34.9 \mathrm{~kg} / \mathrm{m}^{2}\right), 11$ had obesity class II $\left(B M I=35-39.9 \mathrm{~kg} / \mathrm{m}^{2}\right)$ and 34 had obesity class III $\left(\right.$ BMI $\left.>40 \mathrm{~kg} / \mathrm{m}^{2}\right)$. Table 1 shows the main characteristics of all patients and of the subgroups according to the number of risk factors for MetS.

Weight, BMI, WC and BF were significantly higher in patients of Group III in comparison with patients of Group I (all p < 0.001). In addition, Group III had higher systolic (SBP, $131.8 \pm 9.5 \mathrm{mmHg}$ versus 120.6 $\pm 11.9 \mathrm{mmHg} ; \mathrm{p}<0.05)$ and diastolic blood pressure (DBP, 84.1 $\pm 7.1 \mathrm{mmHg}$ versus $77.7 \pm 4.4 ; \mathrm{p}<0.05$ ) in comparison with Group I. Patients of Group I had REE of $1,560.0 \pm 201.9 \mathrm{kcal} /$ day - a value significantly lower than those observed in Group II $(1,975.7 \pm$ $325.6 \mathrm{kcal} /$ day; $\mathrm{p}<0.05)$ and III $(2,267.1 \pm 487.7$ $\mathrm{kcal} /$ day; $\mathrm{p}<0.001)$.

Patients in Group I had lower levels of fasting glucose $(\mathrm{p}<0.05)$, triglycerides $(\mathrm{p}<0.001)$, insulin $(\mathrm{p}<0.05)$ and HOMA-IR $(\mathrm{p}<0.001)$ in comparison with the other two groups. Fasting glucose $(\mathrm{p}<0.05)$ and triglycerides levels $(\mathrm{p}<0.001)$ were also lower in Group II compared to Group III. Table 2 summarizes the biochemical and hormonal findings.

Among all patients absolute serum leptin levels (LepA) were $37.5 \pm 16.9 \mathrm{ng} / \mathrm{mL}$ (range $8.3-81.9 \mathrm{ng} /$ $\mathrm{mL}$ ), BF was $52.8 \pm 16.5 \mathrm{~kg}$ (range $25.4-88.2 \mathrm{~kg}$ ) and LepBF was $0.73 \pm 0.29 \mathrm{ng} / \mathrm{mL} / \mathrm{kg}$ (range $0.19-1.35$ $\mathrm{ng} / \mathrm{mL} / \mathrm{kg}$ ). LepA was positively correlated with weight $(\mathrm{r}=0.37 ; \mathrm{p}=0.008)$, BMI $(\mathrm{r}=0.48 ; \mathrm{p}<0.001)$, WC $(\mathrm{r}=0.31 ; \mathrm{p}<0.05)$ and $\mathrm{BF}(\mathrm{r}=0.52 ; \mathrm{p}<0.001)$, whereas LepBF was inversely correlated with weight $(r=-0.31$; 
$\mathrm{p}<0.05)$ and $\operatorname{REE}(\mathrm{r}=-0.34 ; \mathrm{p}=0.01)$. The number of risk factors for MetS did not correlate with LepA $(\mathrm{r}=-0.02 ; \mathrm{p}=0.9)$, but it showed a significant negative correlation with LepBF $(\mathrm{r}=-0.32 ; \mathrm{p}=0.02)$ (Figure $\mathrm{l})$.

LepA did not differ among the groups (Group I: $33.59 \pm 14.79 \mathrm{ng} / \mathrm{mL}$; Group II: $42.42 \pm 17.59 \mathrm{ng} /$ mL; Group III: $34.48 \pm 17.01 \mathrm{ng} / \mathrm{mL}$ ), regardless of significant differences in weight, $\mathrm{BMI}, \mathrm{WC}$ and $\mathrm{BF}$ (Table 3). However, LepBF was $0.58 \pm 0.27 \mathrm{ng} / \mathrm{mL} / \mathrm{kg}$ in patients of Group III, a value significantly lower than those observed in patients of Group I $(0.81 \pm 0.22 \mathrm{ng} /$ $\mathrm{mL} / \mathrm{kg}, \mathrm{p}=0.03)$ and Group II $(0.79 \pm 0.30 \mathrm{ng} / \mathrm{mL} /$ $\mathrm{kg}, \mathrm{p}=0.02$ ) (Figure 2). There was no clear cut-off value for LepA or LepBF that could distinguish obese patients according to the number of risk factors for MetS.
We have performed analysis of the LepA and LepBF for each risk factor associated with MetS separately (Table 3 ). In patients with hypertriglyceridemia (triglycerides levels $\geq 150 \mathrm{mg} / \mathrm{dL}, \mathrm{n}=26$ ), LepBF was significantly higher than in those 25 patients with normal triglycerides levels $(0.83 \pm 0.26 \mathrm{ng} / \mathrm{mL} / \mathrm{kg}$ versus 0.63 $\pm 0.28 \mathrm{ng} / \mathrm{mL} / \mathrm{kg} ; \mathrm{p}=0.01)$. As shown in Table 3 , LepBF tended to be lower in patients with abnormal blood pressure $(0.70 \pm 0.31 \mathrm{ng} / \mathrm{mL} / \mathrm{kg}$ versus 0.78 $\pm 0.23 \mathrm{ng} / \mathrm{mL} / \mathrm{kg})$, hyperglycemia $(0.68 \pm 0.32 \mathrm{ng} /$ $\mathrm{mL} / \mathrm{kg}$ versus $0.79 \pm 0.24 \mathrm{ng} / \mathrm{mL} / \mathrm{kg})$ and low HDLcholesterol $(0.69 \pm 0.26 \mathrm{ng} / \mathrm{mL} / \mathrm{kg}$ versus $0.77 \pm 0.32$ $\mathrm{ng} / \mathrm{mL} / \mathrm{kg}$ ), but none of these values reached statistical significance. In contrast, LepA did not differ in the presence or absence of the risk factors.

\begin{tabular}{|c|c|c|c|c|}
\hline & $\begin{array}{l}\text { All patients } \\
(\mathrm{n}=51)\end{array}$ & $\begin{array}{l}\text { Group I } \\
(n=13)\end{array}$ & $\begin{array}{l}\text { Group II } \\
(n=21)\end{array}$ & $\begin{array}{l}\text { Group III } \\
(n=17)\end{array}$ \\
\hline Age (years) & $36.7 \pm 10.0$ & $37.7 \pm 8.6$ & $35.8 \pm 12.1$ & $36.9 \pm 8.5$ \\
\hline Weight (kg) & $119.0 \pm 28.1$ & $97.0 \pm 22.1$ & $119.1 \pm 21.8$ & $135.2 \pm 29.0^{\mathrm{a}}$ \\
\hline Sex (females:males) & $46: 5$ & $12: 1$ & $19: 2$ & $11: 6$ \\
\hline Race (Caucasians:Afro-Brazilians) & $46: 5$ & 13:0 & $19: 2$ & $14: 3$ \\
\hline Weight (kg) & $119 \pm 28.1$ & $97.0 \pm 22.1$ & $119.1 \pm 21.8$ & $135.2 \pm 29.0^{\mathrm{a}}$ \\
\hline BMI $\left(\mathrm{kg} / \mathrm{m}^{2}\right)$ & $46.2 \pm 10.0$ & $39.3 \pm 8.6$ & $46.8 \pm 10.2$ & $50.6 \pm 8.2^{\mathrm{a}}$ \\
\hline WC (cm) & $125.1 \pm 18.5$ & $114.9 \pm 19.1$ & $124.0 \pm 16.7$ & $134.3 \pm 16.4^{b}$ \\
\hline $\mathrm{SBP}(\mathrm{mmHg})$ & $127.0 \pm 12.2$ & $120.6 \pm 11.9$ & $127.1 \pm 13.1$ & $131.8 \pm 9.5^{b}$ \\
\hline $\mathrm{DBP}(\mathrm{mmHg})$ & $82.4 \pm 6.5$ & $77.7 \pm 4.4$ & $83.8 \pm 5.9$ & $84.1 \pm 7.1^{b}$ \\
\hline $\mathrm{BF}(\mathrm{kg})$ & $52.8 \pm 16.5$ & $41.3 \pm 16.1$ & $53.9 \pm 14.6$ & $60.2 \pm 14.9^{c}$ \\
\hline $\operatorname{REE}(\mathrm{kcal} / \mathrm{d})$ & $1,967.1 \pm 449.3$ & $1,560.0 \pm 201.9^{d}$ & $1,975.7 \pm 325.6$ & $2,267.1 \pm 487.7$ \\
\hline
\end{tabular}

BMI: body mass index; WC: waist circumference; SBP: systolic blood pressure; DBP: diastolic blood pressure; BF: body fat; REE: resting energy expenditure. ${ }^{a} p<0.001$ versus Group I; ${ }^{b} p<0.05$ versus Group I; ${ }^{c} p<0.01$ versus Group I; ${ }^{d} p<0.05$ versus Group II and $p<0.001$ versus Group III.

Table 2. Biochemical and hormonal parameters of the whole cohort of patients and in each study group divided according to number of risk factors for metabolic syndrome: Group I (0 or 1), Group II (2), and Group III (3 or 4)

\begin{tabular}{|c|c|c|c|c|}
\hline & $\begin{array}{l}\text { All patients } \\
(n=51)\end{array}$ & $\begin{array}{l}\text { Group I } \\
(n=13)\end{array}$ & $\begin{array}{l}\text { Group II } \\
(n=21)\end{array}$ & $\begin{array}{l}\text { Group III } \\
(n=17)\end{array}$ \\
\hline Fasting glucose (mg/dL) & $107.4 \pm 24.5$ & $88.7 \pm 5.2^{\mathrm{a}}$ & $105.2 \pm 19.6^{b}$ & $124.3 \pm 27.8$ \\
\hline $\mathrm{TC}(\mathrm{mg} / \mathrm{dL})$ & $193.3 \pm 34.5$ & $181.5 \pm 30.2$ & $191.3 \pm 38.3$ & $204.7 \pm 30.8$ \\
\hline Triglycerides (mg/dL) & $161.8 \pm 90.4$ & $100.4 \pm 34.9^{c}$ & $152.0 \pm 111.1^{c}$ & $220.8 \pm 48.2$ \\
\hline HDL-c (mg/dL) & $48.0 \pm 12.0$ & $54.3 \pm 10.1$ & $50.1 \pm 13.0$ & $40.6 \pm 8.4$ \\
\hline LDL-c (mg/dL) & $113.7 \pm 27.7$ & $104.1 \pm 23.1$ & $115.1 \pm 29.8$ & $119.2 \pm 28.0$ \\
\hline TSH (uUl/mL) & $2.41 \pm 1.56$ & $2.18 \pm 1.53$ & $2.38 \pm 1.60$ & $2.61 \pm 1.59$ \\
\hline Free T4 (ng/dL) & $1.21 \pm 0.23$ & $1.23 \pm 0.21$ & $1.19 \pm 0.22$ & $1.23 \pm 0.26$ \\
\hline Insulin (uUl/mL) & $22.95 \pm 12.59$ & $13.06 \pm 5.62^{a}$ & $21.99 \pm 8.43$ & $31.70 \pm 14.85$ \\
\hline HOMA-IR & $6.55 \pm 5.38$ & $2.85 \pm 1.20^{d}$ & $5.75 \pm 2.48$ & $10.36 \pm 7.37$ \\
\hline
\end{tabular}

TC: total cholesterol; HOMA-IR: homeostatic model assessment of insulin resistance index.

a $p<0.05$ versus Group II and Group III; ${ }^{b} p<0.05$ versus Group III; ${ }^{\circ} p<0.001$ versus Group III; d $p<0.001$ versus Group III. 
Table 3. Absolute serum levels of leptin (LepA) and leptinemia adjusted for BF (LepBF) according to the presence or absence of risk factors for metabolic syndrome

\begin{tabular}{|c|c|c|c|c|c|c|c|c|}
\hline & \multicolumn{2}{|c|}{ Blood pressure } & \multicolumn{2}{|c|}{ Fasting glucose } & \multicolumn{2}{|c|}{ Triglycerides } & \multicolumn{2}{|c|}{ HDL-C } \\
\hline & $\begin{array}{l}\text { Normal } \\
(n=15)\end{array}$ & $\begin{array}{c}\text { High } \\
(n=36)\end{array}$ & $\begin{array}{l}\text { Normal } \\
(n=24)\end{array}$ & $\begin{array}{c}\text { High } \\
(n=27)\end{array}$ & $\begin{array}{l}\text { Normal } \\
(n=26)\end{array}$ & $\begin{array}{c}\text { High } \\
(n=25)\end{array}$ & $\begin{array}{l}\text { Normal } \\
(n=24)\end{array}$ & $\begin{array}{c}\text { Low } \\
(n=27)\end{array}$ \\
\hline LepA (ng/mL) & $40.2(16.3)$ & 36.4 (17.3) & $35.3(13.5)$ & 39.5 (19.5) & $40.4(16.5)$ & $34.8(17.2)$ & $36.6(18.6)$ & $38.3(15.6)$ \\
\hline LepBF (ng/mL/kg) & $0.78(0.23)$ & $0.70(0.31)$ & $0.79(0.24)$ & $0.68(0.32)$ & $0.83(0.26)$ & $0.63(0.28)^{\star}$ & $0.77(0.32)$ & $0.69(0.26)$ \\
\hline
\end{tabular}

Data shown as mean (SD).

${ }^{*} p=0.01$ versus normal triglycerides.
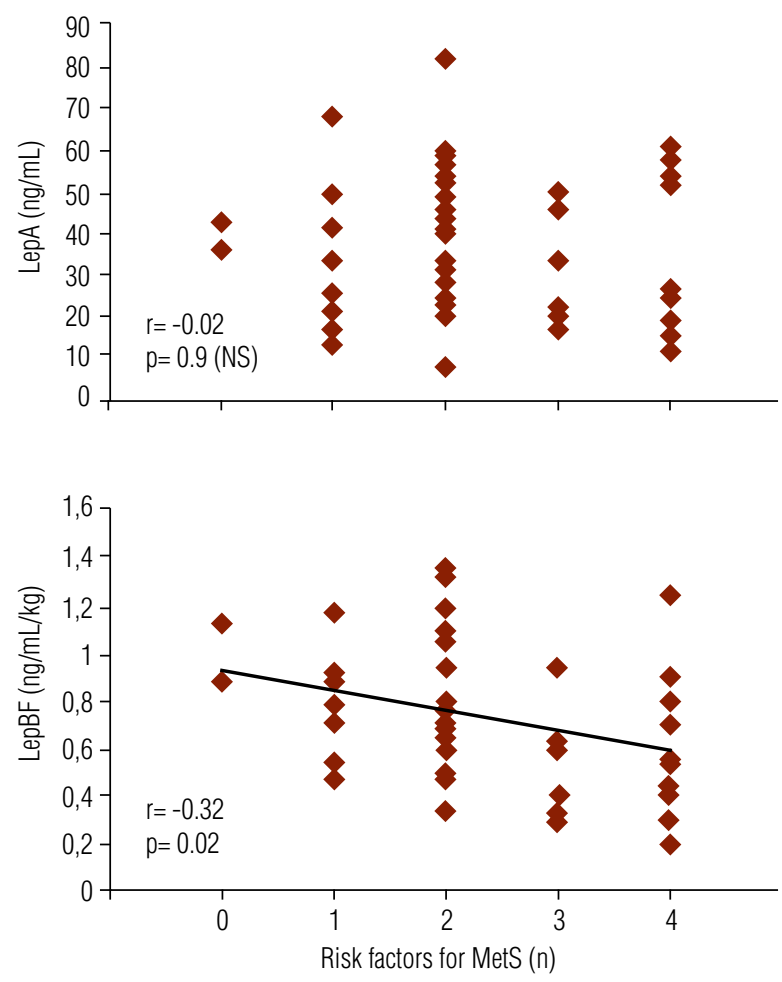

Figure 1. Correlations between absolute serum leptin levels (LepA; ng/mL) and leptinemia adjusted for body fat (LepBF; ng/mL/kg) with the number of risk factors for MetS.

\section{DISCUSSION}

In our cohort of obese individuals, although LepA was positively correlated with weight, $\mathrm{BMI}, \mathrm{WC}$ and $\mathrm{BF}$ as expected, no associations were found between LepA and any component of MetS. In addition, LepA was not associated with severity of MetS since its levels were similar among patients with different degrees of MetS. However, we did observe that leptin levels adjusted for body fat mass (LepBF) were significantly decreased in obese patients with at least three risk factors for MetS. The fact that LepBF was negatively correlated with the number of risk factors provides further evidence that LepBF may be associated with the severity of MetS.
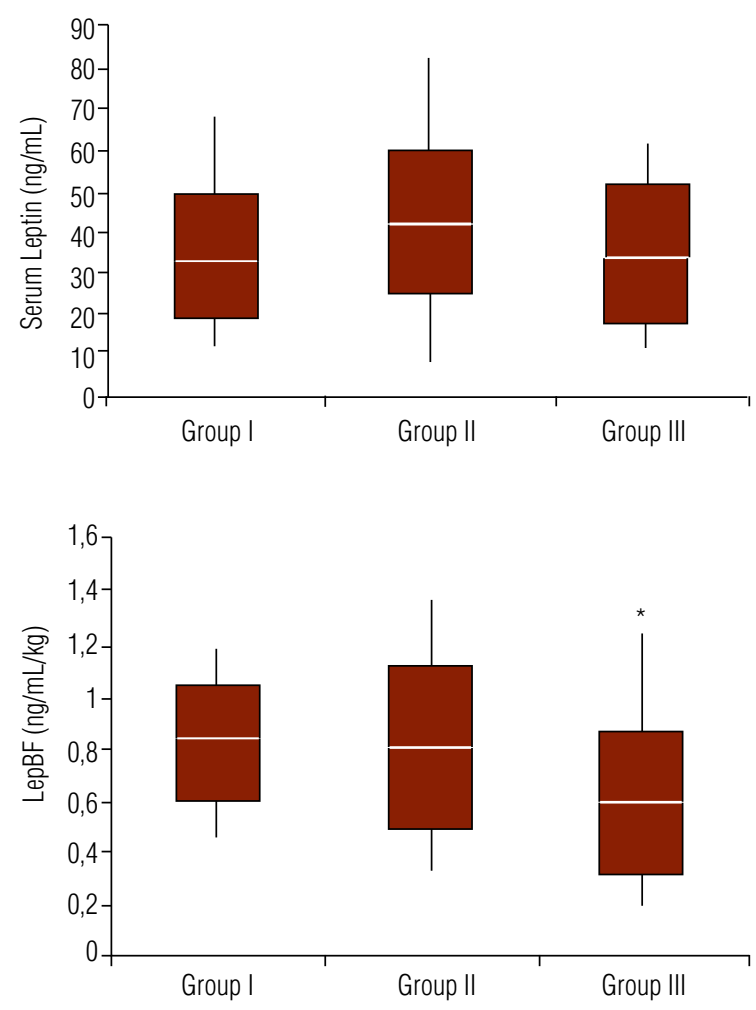

Figure 2. Serum levels of leptin ( $\mathrm{ng} / \mathrm{mL}$ ) and leptinemia adjusted for body fat (LepBF; $\mathrm{ng} / \mathrm{mL} / \mathrm{kg}$ ) in the study groups divided according to number of risk factors for metabolic syndrome: Group I (0 or 1), Group II (2), and Group III (3 or 4). Asterisk denotes p value of 0.03 versus Group I and 0.02 versus Group II.

There have been reports showing positive correlation between leptinemia and risk factors associated with MetS, such as hypertension (26,27), DM (28), hypertriglyceridemia and low HDL-cholesterol (29). However, several studies have been unable to replicate these findings (30-37). It is likely that the contradictions among the studies arise from the fact that leptinemia is not adjusted for the amount of BF in most studies. By adjusting leptinemia we could, for the first time, identify correlations between leptin and MetS. In agreement with our results, another study has clearly demonstrated that high leptin levels have protective actions against the development of diabetes in obesity (38). 
In this study, we showed that obese patients with three or more criteria for MetS have lower levels of leptin adjusted to fat body mass (LepBF), when compared to their obese counterparts with less than three criteria. This observation was not true when LepA was considered. Moreover, we could not establish cut-off values of leptinemia in order to predict the number of criteria fulfilled for MetS. Several studies showed positive correlations between leptinemia and the criteria for MetS, such as hypertension, DM, hypertriglyceridemia and low HDL-c. However, other studies did not replicate those findings. It is possible that these contradictions are attributed to the fact that some of these studies did not adjust leptinemia to the parameters of obesity (weight, BMI and BF) (39). However, when leptinemia is adjusted to those parameters, high leptin levels may have protective action against the development of diabetes in obese patients, in concordance to our findings.

Although the correlation between leptinemia and body weight is unquestionable, we (40) and other investigators $(34,41-43)$ have documented high variability of leptin levels among patients with similar BMI and $\mathrm{BF}$, particularly in obesity. As a consequence, not all obese patients with BMI greater than $40 \mathrm{~kg} / \mathrm{m}^{2}$ present with extremely high levels of leptin, as it would be expected. This is true even in the monogenic syndrome of obesity caused by mutations in the leptin receptor, where circulating levels of leptin are highly variable among affected individuals and not disproportionately elevated (44). In our series, 34 out of 51 subjects had severe obesity with BMI above $40 \mathrm{~kg} / \mathrm{m}^{2}$. Within this subgroup, leptin levels varied 7 -fold (from $11.6 \mathrm{ng} / \mathrm{mL}$ to $81.9 \mathrm{ng} / \mathrm{mL}$; data not shown). Although common obesity is mostly related to leptin-resistance, a subgroup of subjects with severe obesity and inappropriately low circulating levels of leptin was identified in our study by using LepBF instead of LepA in the analysis. In this subgroup of patients, disproportionately low production of leptin by the adipose tissue, and not leptin-resistance, is the possible mechanism to explain their excessive body weight and metabolic abnormalities. In agreement with that observation, mice partially deficient in leptin under high-fat feeding show an increased risk of obesity, hepatic steatosis, glucose intolerance, and hyperlipidemia (45). Moreover, humans heterozygous for mutations of the $O B$ gene with partial leptin deficiency have an increased prevalence of overweight and obesity (12).

In our study, LepBF was inversely correlated with weight and REE. These findings support the evidence that more obese patients - and, therefore, with higher REE, have disproportionately lower leptin levels adjusted for their fat mass. Moreover, the analysis of individual components of the MetS showed a significant association of low LepBF and hypertriglyceridemia. This finding might be explained by the antilipogenic and pro-lipolytic effects of leptin on the metabolism of fatty acids $(33,35,46,47)$. In addition, we observed that LepBF tended to be lower in patients with abnormal blood pressure, hyperglycemia and low HDL-cholesterol, although the values did not reach significance.

Peripheral effects of leptin decreases lipogenesis and protects against excessive weight gain, both acutely and chronically. Accordingly, reduced peripheral actions of leptin would lead to increased lipogenesis and accumulation of lipids in sites other than the adipose tissue - a phenomenon known as lipotoxicity $(14,15)$. There is strong evidence that lipotoxicity takes part in the development of several components of the MetS, such as hepatic steatosis, insulin resistance, dyslipidemia, beta cell failure and T2DM $(48,49)$. When comparing equal masses of visceral and subcutaneous adipose tissue, both secrete similar amounts of lipids to the bloodstream, whereas visceral fat secretes less leptin. In our patients who presented with three or four risk factors for MetS, low leptin levels might reflect the lack of balance between lipid and leptin secretion by visceral and subcutaneous adipose tissue (50). Consequently, less leptin might be available to the peripheral tissues, which may predispose to lipotoxicity and the development of comorbidities associated with MetS in these individuals. However, there was no clear cut-off value of LepBF to identify obese patients with high risk for MetS.

Our study has some limitations. Its cross-sectional design does not allow us to definitively answer whether the lower levels of LepBF observed in our patients is truly involved in the pathogenesis of the MetS, or if it is just a biomarker of the disease. Nevertheless, this situation resembles what is observed in T2DM, in which both abnormal insulin secretion and insulin resistance play a role in the development of the disease (51). In addition, we could not identify any significant correlations between LepBF and additional variables, other than triglycerides. This was probably due to the size of our cohort, which was influenced by the very strict criteria for enrollment in our study, especially the exclusion of severe comorbidities and several medications usually taken by obese subjects with BMI greater than $40 \mathrm{~kg} / \mathrm{m}^{2}$. On the other hand, we were able to have a 
more homogeneous study group for the analysis, avoiding various confounding factors that might influence body weight, LepA and LepBF.

In conclusion, we have found that obese patients with three or more risk factors for MetS, especially those with hypertriglyceridemia, have lower levels of Le$\mathrm{pBF}$ when compared to their obese counterparts with less than three risk factors and normal triglycerides. Considering that our patients with three or more risk factors were heavier and had more elevated triglycerides in comparison with the other groups, and that LepA did not differ among the study groups, our LepBF findings suggest a state of relative leptin deficiency in obesity associated with more advanced stages of MetS. If this hypothesis proves to be true in future studies therapy with leptin or some agonists will be useful in selected obese patients to prevent or to ameliorate some components of MetS, as already reported in various forms of relative leptin deficiency, such as anorexia nervosa, milder forms of hypothalamic amenorrhea, and congenital or acquired lipodystrophy (52).

Disclosure: no potential conflict of interest relevant to this article was reported.

\section{REFERENCES}

1. Obesity: preventing and managing the global epidemic. Report of a WHO consultation. World Health Organ Tech Rep Ser. 2000;894:i-xii, 1-253.

2. IBGE [Internet]. Pesquisa de Orçamentos Familiares - 2002-2003. Comunicação Social [cited 2009 Mar 10]; Available from: http:// www.ibge.gov.br/home/presidencia/noticias/noticia_impressao.php?id_noticia $=278$.

3. Eckel RH, Grundy SM, Zimmet PZ. The metabolic syndrome. Lancet. 2005;365(9468):1415-28.

4. Morton GJ, Cummings DE, Baskin DG, Barsh GS, Schwartz MW. Central nervous system control of food intake and body weight. Nature. 2006;443(7109):289-95.

5. Woods SC, D'Alessio DA. Central control of body weight and appetite. J Clin Endocrinol Metab. 2008;93(11 Suppl 1):S37-50.

6. Farooqi IS, Jebb SA, Langmack $\mathrm{G}$, Lawrence $\mathrm{E}$, Cheetham $\mathrm{CH}$, Prentice AM, et al. Effects of recombinant leptin therapy in a child with congenital leptin deficiency. N Engl J Med. 1999;341(12):879-84.

7. Farooqi IS, Matarese G, Lord GM, Keogh JM, Lawrence E, Agwu $C$, et al. Beneficial effects of leptin on obesity, T cell hyporesponsiveness, and neuroendocrine/metabolic dysfunction of human congenital leptin deficiency. J Clin Invest. 2002;110(8):1093-103.

8. Gibson WT, Farooqi IS, Moreau M, DePaoli AM, Lawrence E, O'Rahilly S, et al. Congenital leptin deficiency due to homozygosity for the Delta133G mutation: report of another case and evaluation of response to four years of leptin therapy. J Clin Endocrinol Metab. 2004;89(10):4821-6.

9. Licinio J, Caglayan S, Ozata M, Yildiz BO, de Miranda PB, O'Kirwan $F$, et al. Phenotypic effects of leptin replacement on morbid obesity, diabetes mellitus, hypogonadism, and behavior in leptindeficient adults. Proc Natl Acad Sci U S A. 2004;101(13):4531-6.
10. Montague CT, Farooqi IS, Whitehead JP, Soos MA, Rau H, Wareham $\mathrm{NJ}$, et al. Congenital leptin deficiency is associated with severe early-onset obesity in humans. Nature. 1997;387(6636):903-8.

11. Ozata M, Ozdemir IC, Licinio J. Human leptin deficiency caused by a missense mutation: multiple endocrine defects, decreased sympathetic tone, and immune system dysfunction indicate new targets for leptin action, greater central than peripheral resistance to the effects of leptin, and spontaneous correction of leptinmediated defects. J Clin Endocrinol Metab. 1999;84(10):3686-95.

12. Farooqi IS, Keogh JM, Kamath S, Jones S, Gibson WT, Trussell $\mathrm{R}$, et al. Partial leptin deficiency and human adiposity. Nature. 2001;414(6859):34-5.

13. Muoio DM, Lynis Dohm G. Peripheral metabolic actions of leptin. Best Pract Res Clin Endocrinol Metab. 2002;16(4):653-66.

14. Muoio DM, Dohm GL, Fiedorek FT Jr, Tapscott EB, Coleman RA. Leptin directly alters lipid partitioning in skeletal muscle. Diabetes. 1997;46(8):1360-3.

15. Muoio DM, Dohm GL, Tapscott EB, Coleman RA. Leptin opposes insulin's effects on fatty acid partitioning in muscles isolated from obese ob/ob mice. Am J Physiol. 1999;276(5 Pt 1):E913-21.

16. Beltowski J. Leptin and atherosclerosis. Atherosclerosis. 2006;189(1):47-60.

17. Eriksson M, Johnson $\mathrm{O}$, Boman $\mathrm{K}$, Hallmans G, Hellsten G, Nilsson TK, et al. Improved fibrinolytic activity during exercise may be an effect of the adipocyte-derived hormones leptin and adiponectin. Thromb Res. 2008;122(5):701-8.

18. Paz-Filho GJ, Andrews D, Esposito K, Erol HK, Delibasi T, Wong $M L$, et al. Effects of leptin replacement on risk factors for cardiovascular disease in genetically leptin-deficient subjects. Horm Metab Res. 2009;41(2):164-7.

19. van Dielen FM, van't Veer C, Schols AM, Soeters PB, Buurman WA, Greve JW. Increased leptin concentrations correlate with increased concentrations of inflammatory markers in morbidly obese individuals. Int J Obes Relat Metab Disord. 2001;25(12):1759-66.

20. Brennan AM, Li TY, Kelesidis I, Gavrila A, Hu FB, Mantzoros CS. Circulating leptin levels are not associated with cardiovascular morbidity and mortality in women with diabetes: a prospective cohort study. Diabetologia. 2007;50(6):1178-85.

21. Lawlor DA, Smith GD, Kelly A, Sattar N, Ebrahim S. Leptin and coronary heart disease risk: prospective case control study of British women. Obesity (Silver Spring). 2007;15(7):1694-701.

22. Piemonti L, Calori G, Mercalli A, Lattuada G, Monti P, Garancini MP, et al. Fasting plasma leptin, tumor necrosis factor-alpha receptor 2, and monocyte chemoattracting protein 1 concentration in a population of glucose-tolerant and glucose-intolerant women: impact on cardiovascular mortality. Diabetes Care. 2003;26(10):2883-9.

23. Söderberg S, Ahren B, Jansson JH, Johnson O, Hallmans G, Asplund $\mathrm{K}$, et al. Leptin is associated with increased risk of myocardial infarction. J Intern Med. 1999;246(4):409-18.

24. Wallace AM, McMahon AD, Packard CJ, Kelly A, Shepherd J, Gaw $A$, et al. Plasma leptin and the risk of cardiovascular disease in the west of Scotland coronary prevention study (WOSCOPS). Circulation. 2001;104(25):3052-6.

25. Alberti KG, Zimmet $P$, Shaw J. Metabolic syndrome - a new world-wide definition. A Consensus Statement from the International Diabetes Federation. Diabet Med. 2006;23(5):469-80.

26. Agata J, Masuda A, Takada M, Higashiura K, Murakami H, MiyazakiY, et al. High plasma immunoreactive leptin level in essential hypertension. Am J Hypertens. 1997;10(10 Pt 1):1171-4.

27. Uckaya G, Ozata M, Sonmez A, Kinalp C, Eyileten T, Bingol N, et al. Plasma leptin levels strongly correlate with plasma renin activity in patients with essential hypertension. Horm Metab Res. 1999:31(7):435-8. 
28. McNeely MJ, Boyko EJ, Weigle DS, Shofer JB, Chessler SD, Leonnetti $\mathrm{DL}$, et al. Association between baseline plasma leptin levels and subsequent development of diabetes in Japanese Americans. Diabetes Care. 1999;22(1):65-70.

29. Valle M, Gascon F, Martos R, Bermudo F, Ceballos P, Suanes A. Relationship between high plasma leptin concentrations and metabolic syndrome in obese pre-pubertal children. Int J Obes Relat Metab Disord. 2003;27(1):13-8.

30. Seck T, Englaro P, Blum WF, Scheidt-Nave C, Rascher W, Ziegler R, et al. Leptin concentrations in serum from a randomly recruited sample of 50- to 80-year-old men and women: positive association with plasma insulin-like growth factors (IGFs) and IGF-binding protein-3 in lean, but not in obese, individuals. Eur J Endocrinol. 1998;138(1):70-5.

31. Wang G, Tang J, Chen M. [Association of serum leptin concentrations with blood pressure]. Zhonghua Yi Xue Za Zhi. 1999;79(9):664-7.

32. Abdelgadir M, Elbagir M, Eltom M, Berne C, Ahren B. Reduced leptin concentrations in subjects with type 2 diabetes mellitus in Sudan. Metabolism. 2002;51(3):304-6.

33. Haluzik M, Fiedler J, Nedvidkova J, Ceska R. Serum leptin levels in patients with hyperlipidemias. Nutrition. 2000;16(6):429-33.

34. Liuzzi A, Savia G, Tagliaferri M, Lucantoni R, Berselli ME, Petroni $\mathrm{ML}$, et al. Serum leptin concentration in moderate and severe obesity: relationship with clinical, anthropometric and metabolic factors. Int J Obes Relat Metab Disord. 1999;23(10):1066-73.

35. Marinari GM, Scopinaro N, Adami GF. Leptin and HDL-cholesterol in non-diabetic normotensive subjects. Obes Surg. 2001;11(3):252-3.

36. Marita AR, Sarkar JA, Rane S. Type 2 diabetes in non-obese Indian subjects is associated with reduced leptin levels: study from Mumbai, Western India. Mol Cell Biochem. 2005;275(1-2):143-51.

37. Sayeed MA, Azad Khan AK, Mahtab H, Ahsan KA, Banu A, Khanam $P A$, et al. Leptin is reduced in lean subjects with type 2 diabetes in bangladesh. Diabetes. Care. 2003;26(2):547.

38. Schmidt MI, Duncan BB, Vigo A, Pankow JS, Couper D, Ballantyne $\mathrm{CM}$, et al. Leptin and incident type 2 diabetes: risk or protection? Diabetologia. 2006;49(9):2086-96.

39. Hu FB, Chen C, Wang B, Stampfer MJ, Xu X. Leptin concentrations in relation to overall adiposity, fat distribution, and blood pressure in a rural Chinese population. Int $\mathrm{J}$ Obes Relat Metab Disord. 2001;25(1):121-5.
40. Rodrigues AM, Radominski RB, Suplicy Hde L, De Almeida SM, Niclewicz PA, Boguszewski CL. The cerebrospinal fluid/serum leptin ratio during pharmacological therapy for obesity. J Clin Endocrinol Metab. 2002;87(4):1621-6.

41. Considine RV, Sinha MK, Heiman ML, Kriauciunas A, Stephens TW, Nyce MR, et al. Serum immunoreactive-leptin concentrations in normal-weight and obese humans. N Engl $\mathrm{J}$ Med. 1996;334(5):292-5.

42. Havel PJ, Kasim-Karakas S, MuellerW, Johnson PR, Gingerich RL, Stern JS. Relationship of plasma leptin to plasma insulin and adiposity in normal weight and overweight women: effects of dietary fat content and sustained weight loss. J Clin Endocrinol Metab. 1996:81(12):4406-13.

43. Ostlund RE Jr, Yang JW, Klein S, Gingerich R. Relation between plasma leptin concentration and body fat, gender, diet, age, and metabolic covariates. J Clin Endocrinol Metab. 1996;81(11):3909-13.

44. Faroogi IS, Bullmore E, Keogh J, Gillard J, O'Rahilly S, Fletcher $\mathrm{PC}$. Leptin regulates striatal regions and human eating behavior. Science. 2007;317(5843):1355.

45. Begriche K, Letteron P, Abbey-Toby A, Vadrot N, Robin MA, Bado $A$, et al. Partial leptin deficiency favors diet-induced obesity and related metabolic disorders in mice. Am J Physiol Endocrinol Metab. 2008;294(5):E939-51.

46. Dyck DJ, Heigenhauser GJ, Bruce CR. The role of adipokines as regulators of skeletal muscle fatty acid metabolism and insulin sensitivity. Acta Physiol (Oxf). 2006;186(1):5-16.

47. Paz-Filho GJ, Ayala A, Esposito K, Erol HK, Delibasi T, Hurwitz $\mathrm{BE}$, et al. Effects of leptin on lipid metabolism. Horm Metab Res. 2008;40(8):572-4.

48. Shulman Gl. Cellular mechanisms of insulin resistance. J Clin Invest. 2000;106(2):171-6.

49. Unger RH. Minireview: weapons of lean body mass destruction: the role of ectopic lipids in the metabolic syndrome. Endocrinology. 2003;144(12):5159-65.

50. Unger RH. Lipid overload and overflow: metabolic trauma and the metabolic syndrome. Trends Endocrinol Metab. 2003;14(9):398-403.

51. Caro JF, Kolaczynski JW, Nyce MR, Ohannesian JP, Opentanova I, Goldman WH, et al. Decreased cerebrospinal-fluid/serum leptin ratio in obesity: a possible mechanism for leptin resistance. Lancet. 1996;348(9021):159-61.

52. Foster-Schubert KE, Cummings DE. Emerging therapeutic strategies for obesity. Endocr Rev. 2006;27(7):779-93. 